\title{
Avrupa Birliği Ülkelerinin Ufuk 2020 Programına Katılımı ve Yenilik Üretimi Sürecinde Yükseköğretim Kurumlarının Rolü”
}

\author{
Oğuz Güner \\ Amasya Üniversitesi, Yabancı Diller Yüksekokulu, Amasya \\ ORCID: O. Güner (0000-0003-1619-579X)
}

\begin{abstract}
Özet
Bilgi ve teknolojiye dayalı bir rekabet sürecinin içerisinde olan Avrupa Birliği, bilgi odaklı faaliyetlerini artırmak, bilimsel kabiliyeti güçlendirmek ve yenilik üretimini hızlandırabilmek için çeșitli politika setleri uygulamaya koymuştur. Bunlardan biri de bilim, araștırma ve yükseköğretim politikası içerisinde ele alınan çerçeve programlarıdır. Avrupa Birliği, çerçeve programlarını araçsallaştırarak yenilik üretebilme kapasitesini ve kabiliyetini geliștirmeyi, ekonomik rekabet edebilirlik gücünü artırmayı ve sürdürülebilir büyümeyi tesis edebilmeyi amaçlamaktadır. Çerçeve programlarından sonuncusu 2014-2020 yılları arasında geçerli olan Ufuk 2020'dir. Bu çalıșmanın amacı Avrupa Birliği üye ülkelerinin Ufuk 2020 Programına katılımlarını tartışmak ve yenilik üretimi sürecinde yükseköğretim kurumlarının rolünü ele almaktır. Bu bağlamda öncelikle Ufuk 2020 Programı kavramsal olarak tanımlanmıș, üye ülkelerin program bütçesine sundukları katkılar, katıldıkları proje sayıları ve aldıkları hibeler analiz edilmiștir. Projelere katılan kurumların profilleri ve projeler sonrasında ortaya çıkan yeniliklerde yükseköğretim kurumlarının rolü incelenmiștir. Çalışmada, Ufuk 2020 çerçevesinde proje sayısı ve edinilen hibe miktarı dikkate alındığında AB ülkeleri arasında oldukça heterojen bir dağılımın olduğu ve yükseköğretim kurumları ile șirketler arasında iș birliğinin arttıkça yenilik üretme kabiliyetinin yükseldiği sonucuna ulaşılmıştır.
\end{abstract}

Anahtar Kelimeler: Avrupa Birliği; Ufuk 2020; yenilik; yükseköğretim

\section{Investigation of the EU Countries in Horizon 2020 Program and The Role of Higher Education Institutions in The Process of Innovation}

\begin{abstract}
The European Union, in a competition process based upon information and technology, has started to implement certain policy sets to be able to boost its knowledge-based activities, empower scientific capability and accelerate innovation production. One of these policy sets is the framework programs which is addressed within science, research and higher education policies. Via instrumentalization of the framework programs, the European Union aims to develop its capacity and capability of innovation production, increase its economic competitiveness and provide sustainable growth. Current framework program is Horizon 2020 which is in practice between 2014-2020. This study aims to discuss the European Union countries' participation in Horizon 2020 and elaborate the role of higher education institutions in the process of innovation production. In this context, Horizon 2020 program was conceptually described, the member countries' contribution to the program budget, number of the projects they participated and funds they received were analysed. Additionally, profiles of the institutions participated in the projects and role of the higher education institutions in production of innovation were elaborated. In the study, it is concluded that considering the number of projects and the amount of grants acquired within the framework of Horizon 2020, there is a very heterogeneous distribution among EU countries and the ability to produce innovation increases as cooperation increases between higher education institutions and companies.
\end{abstract}

Key Words: European Union; Horizon 2020; innovation; higher education

\section{Giriş}

Avrupa Birliği'nin (AB) yükseköğretim alanında geliştirdiği iki farklı politika aracı bulunmaktadır. Bunlardan

*Yazışma Adresi / Address for Correspondence:

O. Güner, Email: oguz.guner@amasya.edu.tr

Geliş Tarihi / Received Date: 03.05.2020

Kabul Tarihi / Accepted Date: 29.08.2020

Doi: 10.26701/uad 731286 birincisi bilimsel, eğitsel ve kültürel öğrenme hareketliliği sağlayan ve öğrencilere ve eğitim kurumlarına Avrupalılık bilinci kazandırmayı hedefleyen Erasmus+ programıdır. Bu program genel itibarıyla öğrenci değişim, staj imkânları, gönüllülük hizmetleri gibi bireylerin bilgi ve tecrübelerini artıracak faaliyetleri içermektedir. İkinci politika aracı ise AB'nin ekonomik büyümesini, kalkınmasını, yenilik üretme hızını artırmayı ve araştırma-geliştirme (ar-ge) alanının güçlenmesini hedefleyen çerçeve programlarıdır. Çerçeve programları, himaye ettiği
manlı̆ında tamamlanan “Bilgi Toplumunda Avrupa Birliği Yükseköğretim Politi-

* Istanbul Üniversitesi, SBE Avrupa Birliği Anabilim Dalı'nda Prof.Dr. Arzu Kihtir'in danışmanlı̆̆ı̈nda tama 
araștırma projeleri ile $\mathrm{AB}$ genelinde ve ortak ülkelerde bilimsel bilginin üretilmesi, yenilikçiliğin desteklenmesi, patent üretiminin artırılmasını ve ekonomik büyümenin sağlanmasını hedeflemektedir.

AB, Avrupa Araştırma Alanı ile bilim ve teknoloji alanında yapılan çalışmaları da Ortak Pazar gibi tek bir çatı altına almayı planlamış ve bu çalışmaların $\mathrm{AB}$ içerisinde parçalanmaması, makro düzeyde ele alınarak $A B$ genelinde daha fazla istihdam yaratılması ve AB'nin genel bir özne olarak küresel pazardaki rekabet edebilirliğinin artırılmasını hedeflemiştir. AB'nin bu alanda yaptığı çalışmalar için en büyük mali kaynağı çerçeve programlarıdır. İlk kez 1984 yilında uygulamaya konulan çerçeve programlarının kaynakları $\mathrm{AB}$ ülkelerinin Birliğin ortak bütçesine yaptıkları katkılardan ve Gayri Safi Yurtiçi Hasılalarından çerçeve programlarına katılımları için ödedikleri katılım paylarından oluşmaktadır (Akses, 2010).

Bu çalışmada 2014 yllından beri yürürlükte olan Ufuk 2020 programına $A B$ ülkelerinin katılımı tartışılmaktadır. Ayrıca Avrupa Komisyonu raporlarına dayanarak yükseköğretim kurumlarının yaptığı iş birliklerinin yenilik üretim sürecine ne ölçüde katkı yaptığı ele alınacaktır. Çalışmanın ilk kısmında Çerçeve Programları ve Ufuk 2020 Çerçeve Programı tanıtılmış, ikinci kısmında Avrupa Komisyonu verilerinden yararlanarak Birlik ülkelerinin ne kadar projeye katıldığı ve ne kadar hibe aldığ tartışılmış, son kısımda ise yükseköğretim kurumlarının yükseköğretim kurumları, araştırma merkezleri ve özel şirketlerle yaptığı iş birliklerinin yenilik üretme sürecine ne ölçüde katkı yaptığı ele alınmıştır. Çalışmada, AB ülkelerinin Ufuk 2020 ülkelerinden faydalanma düzeylerinin homojen olmadığı, yükseköğretim kurumlarının ise özel şirketlerle yaptıkları ortaklıklarda daha fazla yenilik üretebildiği sonucuna ulaşılmıştır.

\section{2. ÇERÇEVE PROGRAMLARININ YÜKSEKÖĞRETIMDEKI ROLÜ VE YENILIK ÇIKTILARI}

Araştırma faaliyetleri $\mathrm{AB}$ genelinde ekonomik büyümenin desteklenmesi ve küresel ekonomi bağlamında istihdamın artırılması için önemli rol oynayan sacayaklarından bir tanesidir. Çerçeve programları, AB'nin ekonomik ve sosyal politikasına dair amaçlarının araştırma politikası ile yerine getirilmesinde kullanılan önemli bir araçtır. Avrupa Araştırma Alanı́nın bünyesinde gerçekleştirilen 7 yıllık çerçeve programları ile araştırma ve yenilik projelerine fonlar tahsis edilmekte ve bilimsel ve teknolojik yenilik faaliyetleri desteklenmektedir (European Defence Agency, 2018).

$\mathrm{AB}$ çerçeve programları Avrupa'nın ar-ge harcamalarına önemli ölçüde katkı sunmaktadır. 2014-2020 yılları arası için uygulamaya konulmuş olan Ufuk 2020 programı ile yaklaşık 80 Milyar Euro'luk bir bütçe ar-ge ve yenilik faaliyetlerinde kullanılmak üzere tahsis edilmiştir. Bilimsel ve teknolojik faaliyetlerin finansal olarak desteklenmesinin yanı sıra araştırma kuruluşları, üniversiteler ve özel firmalar arasındaki uluslararası iş birliğinin de geliştirilmesi hedeflenmektedir. 2020 yilı sonuna kadar devam edecek olan Ufuk 2020 Çerçeve Programı bünyesinde gerçekleştirilen araştırma ve yenilik faaliyetleri, AB'nin yükseköğretim, bilim ve araştırma çerçevesinde gerçekleştirdiği politikaların yenilik üretimine ne ölçüde katkı sunduğunu göstermektedir.

$\mathrm{AB}$, çerçeve programları ile yenilik üretimini amaçlanmaktadır. Nitekim 21. yüzyılın özellikle ikinci yarısından itibaren geleneksel sanayi toplumu anlayışı terk edilerek bilgi toplumuna doğru bir geçiş yaşanmıştır. Bu toplum; bilginin yön ve şekil verdiği, bilgi üretiminde çalışan personel sayısının arttığı ve üretim ve hizmet ekonomisinin yanı sıra bilginin temel kaynak olduğu yeni istihdam alanlarının ve ekonomilerin oluştuğu bir toplum olmuștur. $\mathrm{Bu}$ toplumda büyüme ve kalkınmanın anahtarı, yeni bilginin üretilerek yaratıclıkla güçlendirilmesi ve ticari değer kazandırılarak 'yenilik' olarak ortaya çıkmasıdır. Yenilik bilgiden türemektedir. Sahip olunan bilginin zenginleștirilmesi ile yeni bir şeylerin ortaya konulmasıdır. Bu, yeni bir ürün, yeni bir hizmet veya yeni bir yöntem olabilmektedir (Kalsson vd., 2009:2-4).

Yenilik, ekonomik büyümenin ve toplumsal kalkınmanın günümüzde en önemli motorudur. Yeni sistemlerin, yeni fonksiyonların ve yeni örgütlerin geliștirilmesi de yenilik olarak kabul edilmektedir. Bunlar bilimsel veya teknolojik olmanın yanı sıra toplumun taleplerine cevap verecek yeni hizmetler de olabilmektedir. Ekonomik büyümeye katkı sunma, istihdam olușturma, yoksulluğu azaltma, güvenliği artırma, daha iyi yaşam kalitesi sunma ve sürdürülebilir kalkınmayı sağlama gibi amaçlar taşıyan gelişmeler de toplumsal fayda sağladığı için yenilik olarak kabul edilebilmektedir. Bu faydaların sağlanabilmesi için bilgi, beșerî sermaye, bütçe ve altyapı unsurlarının gelişmiş olması gerekmektedir. Yenilik yaratma iddiasında bulunan ülkenin mali ve finansal çevre, tasarım kapasitesi, örgütsel esneklik, ağ oluşturma becerisi ve girişimcilik gibi temel parametreleri de etkin bir şekilde kullanabiliyor olması gerekmektedir. Bu bağlamda yenilik politikalarının diğer politika alanları ile yakın ilişkide olması gerekmektedir. Bireylerin risk alabilme becerileri, ülkedeki kaliteli eğitim ve araştırma sistemi bu hususta önem arz etmektedir. Yenilik politikasi; bilim ve eğitim politikası, sosyal politika ve sağlık politikası, çevre politikası ve sanayi politikası, istihdam politikası ve piyasa politikası gibi birçok politika alanını ilgilendirdiği için çok boyutlu olarak ele alınması gerekmektedir (Conceiçao ve Heitor, 2005:1-3).

Yenilik kavramı bilim, teknoloji ve ar-ge ile çok yakından ilişskilidir. Hatta hükümetlerin veya devletlerin bilim veya araştırma politikası olarak adlandırdığı süreç 1960'lı yıllardan sonra yenilik politikası olarak anılmaya veya alg1lanmaya başlamıştır. Şu an bilim veya araştırma alanında yapılan her çalışmanın yenilik ürettiğini söylemek doğru 
olmaz ancak günümüzdeki politika araçlarının büyük bir kısmı bilimsel, uygulamalı veya teknolojik bilgi üretmeyi amaç edinmektedir. Bu bağlamda yeni bilgi üretmeyi hedefleyen politika araçları için yenilikçilik kavramının kullanılması yanlış olmayacaktır. Tam bu noktada gelişmiş ve gelişmemiş ülkeler arasında da bir ayrım yapılmalıdır. Gelişmiş ülkeler politika tasarlama sürecinde kurumsal bakiyeleri ve tecrübeleri itibarıyla daha esnek bir mevzuat belirlerken, gelişmekte olan ülkeler daha sıkı ve daha bağlayıcı mevzuat geliştirerek bürokratik süreçler itibarıyla kimi zaman tıkanıklığa sebebiyet verebilmektedirler. Özellikle AB gibi ileri düzey entegrasyonun sağlandığı bölgelerde ülkelerin politika tasarımları birbirlerine daha da yakınsanmakta ve gittikçe benzeşmektedir. Bilgi ve iletişim teknolojilerinin hiç olmadığı kadar güçlü olduğu bu çağda başta $A B$ üyesi ülkeler olmak üzere dünyadaki ülkelerin bilim, araştırma, yenilik gibi politika setleri incelendiğinde birçok benzerliğin çıkması gayet olağan bir durumdur (Akçomak, 2016:510-525).

AB'nin fon desteği verdiği program ve projelerde genel olarak çıktıların ticarileşebilmesi vurgusu yapılmakta ve üniversitelerin KOBI'ler ile kurulan iş birlikleri desteklenmektedir. AB'den bir yenilik üretme iddiası ile fon alabilmek için fon veren kuruluşun soracağ ${ }_{1}$ 'Neden?' sorusuna tatmin edici bir cevap vermek gerekmektedir. $\mathrm{Bu}$ soruya birçok cevap verilebilir ancak temel olarak 4 argümandan birinin sunulması gerekmektedir. Bunlar; piyasa başarısızlığı, bilginin yayılması, bilginin aktarımı ve hibenin önemidir. Piyasa başarısızlığı, piyasada bulunmayan, eksikliği hissedilen veya piyasada arz edildiğinde talep oluşturabilecek ürün veya hizmetleri kapsar. Piyasaya bir ürün veya hizmeti sokabilmek için yeterli altyapı ve bütçenin olmaması AB'den fon alabilmek için bir gerekçedir. Piyasada yenilik üretebilmek için ar-ge faaliyeti gerçekleştirme ve risk sermayesine sahip olma hususunda oldukça kısıtlı bütçeleri olan firmaların bu fonlarla piyasaya girebilmesi AB fonlarının firma ve diğer yenilikçi aktörlere güven kazandırması ve bunun diğer yenilikçiler tarafından örnek alınması anlamında önemli bir kazanımdır. Projenin fonlanması ile alınan risk paylaşılmaktadır. Argümanlardan ikincisi bilginin yayılmasıdır. Sunulan araştırma, geliştirme veya yenilik projelerinin proje katılımcılarına değil toplum yararına bir çıtı sunması gerekmektedir. Proje sonrasında ortaya çıkan sonucun topluma bir katkı sunması ve toplumun da bu sonuçtan istifade etmesi hedeflenmektedir. Bu projenin gerçekleştirilmesi genellikle temel araştırma faaliyetleri ile mümkün olabilmektedir. Bu tür araştırmaların maddi karşılığı oldukça düşük olabilir veya hiç olmayabilir. Bu bağlamda araştırmacıların kendi imkânları ile gerçekleştirebilecekleri araştırmalar değildirler. Bu yüzden bu tür projeler devletler tarafından fonlanmaktadır. Avrupa Birliği'nin bu tür projelere hibe desteği \%100 oranındadır. Proje sonunda ortaya çıkan sonuç, bilgi veya çıtının herhangi bir çıkar gözetilmeksizin neşredilmesi ve kamuya yayılması projenin en önemli kısmıdır. Argümanlardan üçüncüsü bilginin aktarımıdır. Piyasada ihtiyaç duyulan yeniliğin üretilmesi sürecinde genellikle bir üniversitenin veya bir araştırma kuruluşunun katkısı bulunmaktadır. Üniversitelerin ve araştırma kuruluşlarının şirketlerle birlikte ürettiği bilgi, ürün veya hizmete dönüşerek piyasada bir yenilik oluşur. Bu sürece de bilgi aktarımı denir. Argümanlardan sonuncusu ise hibenin önemidir. Projenin kapsamı ve içeriği, projeyi uygulamadaki risk, proje ekibinin büyüklüğü gibi kavramlar proje hibesinin önemini belirler. Proje için harici bir hibe fırsatının olup olmadığı, projenin piyasada ne tür bir ihtiyacı kapatacağı gibi mefhumlar da hibeye önem katmaktadır (Harris, 2007:9-13).

Ufuk 2020 öncesindeki 7. Çerçeve Programı 'Avrupa Araştırma Alanı' kurulmasını mümkün kılmıştır. Bu alan sayesinde ülkeler arasında iş birliği teşvik edilmiş, araştırmacıların yürüttüğü faaliyetler desteklenmiş ve özellikle araştırmacı hareketliliği ve kariyer gelişim programları ile araştırma ve teknoloji alanında insan potansiyelinin geliştirilmesi hedeflenmiştir. 2007-2013 yıllarını kapsayan 7. Çerçeve Programı, yaşanan finansal krize siyasi bir cevap niteliği kazanmış ve Avrupa Komisyonu'nun Ekonomik Kurtarma Planı'nın bir parçası olmuştur. Amaç; akıllı yatırımları, temiz teknolojileri, yeniliği ve ekonomiyi geliştirmek, güçlendirmek ve zenginleştirmektir. Aynı hedef ve içerik program itibarıla benzer, ifade itibarıla biraz revize edilerek Avrupa 2020 Stratejisi'nde 'akıllı, sürdürülebilir ve kapsayıcı büyüme’ sloganıyla vücut bulmuştur. Akıllı büyüme ifadesinin de 'bilgi ve yeniliğe dayalı bir büyüme modeli' olduğu belirtilmiștir. Yine Avrupa 2020 Stratejisi'nde, Yenilik Birliği (Innovation Union) inisiyatifi kurulmuş ve araştırma ve yenilik faaliyetlerine $A B$ düzeyinde hareket programı oluşturulmuştur. Ufuk 2020 Programı́nın arka planında yeniliğe güçlü bir vurgu bulunmaktadır (Sabadie ve Kwiatkowski, 2016:2-4).

Avrupa Komisyonu tarafindan fonlanan projelerin yenilikçi çıktılarına dair şu bulgular tespit edilmiştir (Pesole ve Nepelski, 2016:18);

- 7. Çerçeve Programı ve Ufuk 2020 projelerinde, proje başına yaklaşık olarak 1.87 yenilik üretmiştir.

- Ortaya çıkan her yenilik başına 1.9 kurum (araştırma merkezi, üniversite, KOBİ, sivil toplum kuruluşu gibi) paydaş (katılımcı) olmuştur.

- Üretilen yeniliklerin büyük bir kısmı 'bilginin işlenmesi veya yazılım geliştirme’ şeklinde gerçekleşmiştir. Çok az bir kısmı ise 'donanım geliştirme' yeniliği olarak vücut bulmuştur.

- Ortaya çıkan yeniliklerin \%63’ü 'yüksek potansiyel ve ticarileşme’ değeri taşımaktadır.

- Ortaya çıkan yeniliklerin \%55'inin 'birden fazla sahibi' (multiple owners) bulunmaktadir.

- Yüksek potansiyelli yeniliklerin \%74’ü, proje inceleme sürecinin nihai değerlendirme kısmında revize edilen/düzenlenen projelerdir. Dolayısıyla yeni fikir ve 
teknolojilerin, AB projeleri ile olgunlaştığı ve projeler ilerledikçe proje fikirlerinin de yüksek potansiyele kavuştuğu söylenebilmektedir.

AB’nin çerçeve programları fonları yalnızca Birlik üyesi ülkeler tarafından kullanılmamaktadır. Bu fonlar sayesinde dünyanın dört bir yanında birçok ar-ge, bilim ve yenilik faaliyetleri gerçekleştirilmektedir. Kanser teşhis ve tedavilerindeki ilerlemelerden yeni gezegenlerin keşfine, hidrojen yakıtlı araçların geliştirilmesi ve yaygınlaştırılmasından, mevcut bataryalardan 100 kat daha güçlü şarj bataryalarının geliştirilmesine kadar birçok faaliyet bu fonlar sayesinde gerçekleşmiştir. AB çerçeve fonlarıyla Batı Afrika'da 1,5 milyondan fazla çocuğa Ebola Aşısı vurulmuştur. Ebodac projesi ile de Sierra Leone bölgesinde Ebola'ya karşı koruma faaliyetleri yürütülmüştür. Abiomater projesi ile deri altına enjekte edilebilen implant lens materyalleri geliştirilmiştir. Lingvist projesi ile yabancı dil öğrenme sürecinde nörolinguistik metotların geliştirilmesi desteklenmiştir. Deepegs projesi ile yerin yaklaşık $4.5 \mathrm{~km}$ altında sondaj çalışmaları yapılarak temiz jeotermal kaynakları aranmıştır. Strenght2Food projesi ile temiz ve güvenilir gıda tedarik zinciri kurulabilmiştir. E-Rare3 projesi ile tıpta nadir hastalıklar olarak bilinen hastalıklara dair yapılan bilimsel çalışmaları güçlendirmek için ortak platform ve iş birliği ağ geliştirilmiştir. Conquer projesi ile vücut sıvılarının akışlarını görselleştirebilen moleküler görüntüleme sistemi geliştirilmiştir (European Commission, 2018). Bu ve benzeri birçok proje AB tarafindan fonlanarak yenilikçi fikirler desteklenmeye devam etmektedir. $\mathrm{AB}$ çerçeve programları ile yenilik üretimine önemli katkıların sunulduğu bilinmektedir.

\section{UFUK 2020 PROGRAMI (2014-2020), KAPSAMI, IÇERIĞi VE BÜTÇESI}

2014 yılında yürürlüğe giren ve 2020 yılı sonuna kadar yürürlükte kalacak olan Ufuk 2020 programı Avrupa Birliği'nin şimdiye kadarki en yüksek bütçeli araştırma ve yenilik çerçeve programıdır.

Ufuk 2020 programı uygulanması Avrupa Komisyonu'nun 9 farklı komiserliğinin sorumluluğunda 22 farklı kurum (AB düzeyinde, ulusal, bölgesel, özel) tarafından gerçekleştirilmektedir. Dolayısıyla projelerin hayata geçirilmesi ve fonların dağıtılması hususunda farklı yol, yöntem, uygulama ve mevzuatlar bulunabilmektedir. Avrupa Komisyonu bünyesinde Ufuk 2020 bütçesini yöneten kurumlar aşağıdaki gibidir.

\section{Araştırma ve Yenilik Komiserliği}

2. İletişim Ağları, İçerik ve Teknoloji Komiserliği

3. Eğitim ve Kültür Komiserliği

4. Enerji Komiserliği

5. İç Pazar, Sanayi, Girişimcilik ve KOBİ'ler Komiserliği

6. Hareketlilik ve Taşımacılık Komiserliği

7. Göç ve İç İşler Komiserliği
8. Tarım ve Kırsal Kalkınma Komiserliği

9. Ortak Araştırma Merkezi

Program 3 temel sütun üzerine kuruludur. Bunlar; 'toplumsal meydan okumalar,' 'endüstriyel liderlik' ve 'toplum ile ve toplum için bilimdir'. Ufuk 2020 programı araştırma ve yenilik ekosistemini tamamen desteklediği için, bireysel araştırmacı, kamu araştırma kuruluşları, ulusal araştırma kurumları, büyük özel şirketler ve KOBI’ler gibi potansiyel yararlanıcıların katılımını artırmayı hedeflemektedir. Program kapsamının genişletilmesiyle hibe yöntemleri çeşitlenmiş, yararlanıcı sayısı artmış ve kısıtlı bütçe ile daha büyük bir rekabet ortamı tesis edilmiştir (European Parliament, 2015).

Ufuk 2020 programı yararlanıcılara aşağıda belirtilen faaliyet türlerinde fon sağlamaktadır (European Parliament, 2015):

- İş birliği ile gerçekleştirilen ve yeni bilgi veya teknolojilerin geliştirilmesini hedefleyen araștırma ve yenilik faaliyetleri.

- Piyasadaki veya piyasaya yakın ürün ve hizmetlerin desteklenmesi için geliştirilen yenilik faaliyetleri.

- Araştırma ve yenilik projelerinin, programlarının ve politikalarının geliştirilmesi için ağ oluşturma/koordinasyon sağlama amacıyla yapılan faaliyetler.

- Kamuyu ilgilendiren alanlarda yenilik sağlayan ama henüz ticarileşmemiş alanlarda yapılan araştırma, geliştirme ve tasdik çalışmaları.

- Büyük çapta ticari değere kavuşmamış yenilikçi ürün ve hizmetlerin uluslararasılaşabilmesi için gereken risklerin paylaşılması.

- Ödüller.

Ufuk 2020, 2014-2020 yılları arasında geçerli olmak üzere yaklaşık 80 milyar Euro'luk bütçesi ile AB'nin en kapsamlı araştırma ve yenilik programıdır. Hedef, yenilik, keşif ve ilkleri pazara çekebilmek ve ticarileştirebilmektir.

Ufuk 2020 programı, Yenilik Birliği (Inovation Union) ve AB'nin küresel rekabet edebilirliğini güçlendirmeyi hedefleyen Avrupa 2020 inisiyatifinin temel sütunu olup akıllı, sürdürülebilir ve kapsayıcı büyümeyi hedeflemektedir. Araştırma ve yenilik faaliyetlerinin zenginleştirilerek ve güçlendirilerek bilimde mükemmelliğin yakalanması, endüstride liderliğin elde edilmesi ve toplumsal sorunların çözülmesi hedeflenmektedir. Bu bağlamda Avrupa'nın dünya standartlarında bilim üretmesi, yenilik üretiminin önündeki engelleri ortadan kaldırması ve yenilik üretiminde özel sektör ve kamu sektörünün ortak çalışma yapmalarının kolaylaştırılması misyon edinilmiştir. Avrupa Yenilik ve Teknoloji Enstitüsü, Avrupa 2020 hedeflerinin gerçekleştirilmesi sürecine katkı sunmaktadır.

Ufuk 2020 Çerçeve Programı çeşitli temalara göre bütçesini ${ }^{1}$ bölüștürmektedir. Bu temalar 'Bilimde Üstünlük,

1 Ufuk2020 Programı́nın toplam bütçesi 80 Milyar Euro'dur. Ancak 
Toplumsal Meydan Okumalar ve Endüstriyel Liderlik' olarak belirlenmiștir. Temalarına göre bütçe oranları aşağıdaki tabloda belirtilmiştir.

Tablo 1. Ufuk 2020 Detaylı Bütçe Dağılımı

\begin{tabular}{|c|c|c|}
\hline ARAŞTIRMA ALANI & $\begin{array}{c}\text { TOPLAM } \\
\text { BÜTÇEDEKI } \\
\text { ORAN }\end{array}$ & $\begin{array}{l}\text { BÜTÇE } \\
\text { MIKTAR }\end{array}$ \\
\hline BILIMDE ÜSTÜNLÜK & $\% 31,73$ & 24441 \\
\hline Avrupa Araştırma Konseyi & $\% 17$ & 13095 \\
\hline Gelecek teknolojileri ve yeni teknolojiler & $\% 3,5$ & 2696 \\
\hline Marie-Skłodowska-Curie faaliyetleri & $\% 8$ & 6162 \\
\hline Avrupa araştırma altyapısı & $\% 3,23$ & 2488 \\
\hline ENDÜSTRIYEL LIDERLIK & $\% 22,09$ & 17016 \\
\hline Endüstriyel teknolojiler & $\% 17,6$ & 13557 \\
\hline Risk sermayesine erişim & $\% 3,69$ & 2842 \\
\hline KOBI'ler için yenilik & $\% 0,8$ & 616 \\
\hline TOPLUMSAL MEYDAN OKUMALAR & $\% 38,53$ & 29679 \\
\hline Sağlık, demografik değişim ve refah & $\% 9,7$ & 7472 \\
\hline $\begin{array}{l}\text { Gıda güvenliği, sürdürülebilir tarım ve ormancılık, } \\
\text { denizcilik ve su araştırmaları, biyoekonomi }\end{array}$ & $\% 5$ & 3851 \\
\hline Güvenli, temiz, verimli enerji & $\% 7,7$ & 5931 \\
\hline Akıllı, yeşil, entegre taşımacılık & $\% 8,23$ & 6339 \\
\hline $\begin{array}{l}\text { İklim hareketi, çevre kaynakları verimliliği, ham } \\
\text { madde }\end{array}$ & $\% 4$ & 3081 \\
\hline $\begin{array}{l}\text { Değişen dünyada Avrupa, kapsayıcı yenilik, } \\
\text { toplum }\end{array}$ & $\% 1,7$ & 3081 \\
\hline $\begin{array}{l}\text { Güvenli toplum, özgürlüğün korunması, Avrupa } \\
\text { ve vatandaşlarının güvenliği }\end{array}$ & $\% 2,2$ & 1695 \\
\hline TOPLUMLA ve TOPLUM IÇIN BILIM & $\% 0,6$ & 462 \\
\hline $\begin{array}{l}\text { KATILIMIN ARTIRILMASI, ÜSTÜNLÜĞÜN } \\
\text { SAĞLANMASI }\end{array}$ & $\% 1,06$ & 816 \\
\hline AVRUPA YENILIK VE TEKNOLOJI ENSTITÜSÜ & $\% 3,52$ & 2711 \\
\hline $\begin{array}{l}\text { ORTAK ARAŞTIRMA MERKEZI'NIN NÜKLEER } \\
\text { DIŞI FAALIYETLERI }\end{array}$ & $\% 2,47$ & 1903 \\
\hline TOPLAM & $\% 100$ & 77028 \\
\hline NÜKLEER BIIRLEŞME & $\% 45,42$ & 728 \\
\hline NÜKLEER BÖLÜNME & $\% 19,68$ & 316 \\
\hline $\begin{array}{l}\text { ORTAK ARAŞTIRMA MERKEZI'NIN NÜKLEER } \\
\text { FAALIYETLERI }\end{array}$ & $\% 34,9$ & 560 \\
\hline $\begin{array}{l}\text { AVRUPA ATOM ENERJISI TOPLULUĞU'NUN } \\
\text { TOPLAM PAYI }\end{array}$ & $\% 100$ & 1603 \\
\hline
\end{tabular}

Kaynak: European Commission, 2013.

Tabloda belirtildiği üzere Avrupa Komisyonu'nun Ufuk 2020 bütçesinden en fazla fon ayırdığı tema toplumsal meydan okumalardır. Toplumsal sorunların çözümüne yönelik geliştirilecek olan projeler için bu temaya en büyük payın ayrılması bu temadaki sorunların birincil öncelikte olduğunu göstermektedir. Bilimde Üstünlük teması ise \%31.73'lük oran ile ikinci sırada yer almaktadır. Ufuk 2020 bütçesinin yaklaşı \%32'si Avrupa Araştırma Konseyi, Avrupa araştırma altyapısı ve teknolojik gelişmeler için ayrılmıștır. Bütçeden endüstri temasına ayrılan 17 Milyar Euro'luk fon ise endüstri teknolojilerinin geliștirilmesi, KOBI'ler için yenilik faaliyetlerinin geliştirilmesi ve risk sermayesi erişiminde kullanılmak üzere tahsis edilmiştir. Ufuk 2020 bünyesinde desteklenen projelerin ylllara göre sayısı ise aşağıdaki grafikte belirtilmiştir.

\footnotetext{
7 yıllık program döneminde her yıl ortalama \%2 oranında enflasyon artışı göz önünde bulundurularak sabit bütçe olarak 70,2 Milyar Euro belirlenmiştir.

${ }^{2}$ Avrupa Atom Enerjisi Topluluğu'nun bütçesi 5 yıllık zaman dilimi için (2014-2018) hesap edilmiştir. 2019-2020 yılları için 770 Milyon Euro'luk bütçe öngörülmektedir.
}

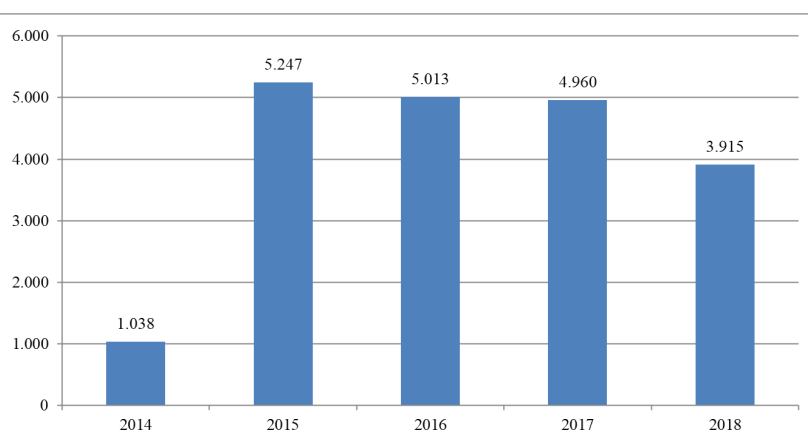

Şekil1. Ufuk 2020 Programı Kapsamında Yıllara Göre Desteklenen Projeler

Kaynak: European Commission, 2018b

Şekilde belirtildiği üzere Ufuk 2020 Programı kapsamında en fazla proje 2015 yllında desteklenmiștir. Programın başladığı sene olan 2014'te 1.038 projeye hibe sağlanmışken 2015 yilında 5.247, 2016 yilında 5.013, 2017 yllında 4.960 projeye hibe tahsis edilmiștir. 2018 yılında ise 3.915 proje Ufuk 2020 hibesi kazanabilmiştir. Dolayısıyla 2015 yılından sonra desteklenen projelerin sayısında azalma olduğu gözlemlenmektedir.

\section{AB ÜLKELERININ UFUK 2020’YE KATILIMLARI VE KAZANIMLARI}

Ufuk 2020 Programı çerçevesinde projeler yürütülmeye devam etmekte olup 2020 yılı sonu itibarıyla çerçeve programı sonra erecek ve 2021-2026 yılları için Ufuk Avrupa isimli çerçeve programı yürürlüğe girecektir. 2014 yılında başlamış olan Ufuk 2020 kapsamında Ocak 2014- Aralık 2018 tarihleri arasında 20 bin 173 proje için hibe sözleșmesi imzalanmış ve 35.56 Milyar Euro bütçe harcaması gerçekleşmiştir. Devam etmekte olan projeler için hibe tahsisleri sürmektedir. Proje başına ortalama 2.22 milyon Euro bütçe harcanmaktadır. Toplamda 20 bin 173 projenin gerçekleştirildiği programda projelere 94 bin 387 katılım gerçekleşmiştir. Bu bağlamda proje başına 4,68 katılımcı düşmektedir (Ufuk 2020 Dashboard). Projelerin katılımcıları farklı ülkelerden farklı kurumlar olabilmekle birlikte aynı ülkeden aynı statüdeki kurumlar da olabilmektedir. Örneğin Ufuk 2020 Programı dâhilinde "Development of a Prophylactic Ebola Vaccine Using an Heterologous Prime-Boost Regimen" isimli ve toplamda 92 milyon 38 bin 481 Euro bütçeli proje kapsamında Birleşik Krallık'tan 2, Hollanda'dan 1 ve Fransa'dan 1 katılımcı kurum bulunmaktadır. ${ }^{3}$ Ufuk 2020 Programı'nın en yüksek bütçeli projesi olan ve EURATOM ${ }^{4}$ bünyesinde yürütülen "Implementation of activities described in the Roadmap to Fusion during Horizon 2020 through a Joint programme of the members of the EUROfusion consortium" isimli füzyon enerjisinin açığa çıkartılmasına dair geliştirilen proje ise toplamda 586 milyon 961 bin 937 Euro bütçe ile farklı ülkelerden 30 katılımcı tarafından yürütülmektedir. ${ }^{5}$ Özetle, Ufuk 2020 projelerine aynı ülkeden birden fazla 3 Proje hakkında detaylı bilgi için: https://cordis.europa.eu/project/rcn/209452_ en.html

${ }^{4}$ Avrupa Atom Enerjisi Topluluğu

${ }^{5}$ Proje hakkında detaylı bilgi için: https://cordis.europa.eu/project/rcn/193159_ en.html 
kurum katılabilmektedir.

Ufuk 2020 Programı kapsamında gerçekleştirilen projelere katılan ülkelerin listesi aşağıdaki tabloda belirtilmektedir.

Tablo 2. Ufuk 2020 Programına AB Ülkelerinin Katılımı (2019)

\begin{tabular}{|c|c|c|c|c|c|}
\hline & Ülke & $\begin{array}{l}\mathrm{H} 2020 \\
\text { Katılımı }\end{array}$ & $\%$ & $\begin{array}{c}\text { Ufuk } 2020 \text { Net } \\
\text { AB Katkısı }\end{array}$ & $\%$ \\
\hline 1. & Almanya & 13.110 & $12,1 \%$ & $€ 6.374 .062 .222$ & $15,6 \%$ \\
\hline 2. & Birleşik Krallık & 12.335 & $11,3 \%$ & $€ 5.567 .422 .199$ & $13,6 \%$ \\
\hline 3. & Fransa & 10.531 & $9,7 \%$ & $€ 4.492 .339 .768$ & $11,0 \%$ \\
\hline 4. & İspanya & 11.220 & $10,3 \%$ & $€ 3.728 .825 .194$ & $9,1 \%$ \\
\hline 5. & İtalya & 10.312 & $9,5 \%$ & $€ 3.460 .132 .706$ & $8,5 \%$ \\
\hline 6. & Hollanda & 6.744 & $6,2 \%$ & $€ 3.111 .856 .274$ & $7,6 \%$ \\
\hline 7. & Belçika & 4.928 & $4,5 \%$ & $€ 1.948 .437 .179$ & $4,8 \%$ \\
\hline 8. & İsveç & 3.274 & $3,0 \%$ & $€ 1.424 .173 .649$ & $3,5 \%$ \\
\hline 9. & Avusturya & 3.044 & $2,8 \%$ & $€ 1.141 .916 .125$ & $2,8 \%$ \\
\hline 10. & Danimarka & 2.451 & $2,3 \%$ & $€ 1.036 .356 .851$ & $2,5 \%$ \\
\hline 11. & Finlandiya & 2.106 & $1,9 \%$ & $€ 912.511 .277$ & $2,2 \%$ \\
\hline 12. & Yunanistan & 3.010 & $2,8 \%$ & $€ 911.056 .593$ & $2,2 \%$ \\
\hline 13. & İrlanda & 1.778 & $1,6 \%$ & $€ 701.722 .110$ & $1,7 \%$ \\
\hline 14. & Portekiz & 2.353 & $2,2 \%$ & $€ 648.433 .650$ & $1,6 \%$ \\
\hline 15. & Polonya & 1.696 & $1,6 \%$ & $€ 382.028 .908$ & $0,9 \%$ \\
\hline 16. & Çek Cumhuriyeti & 1.089 & $1,0 \%$ & $€ 278.025 .582$ & $0,7 \%$ \\
\hline 17. & Macaristan & 913 & $0,8 \%$ & $€ 233.647 .624$ & $0,6 \%$ \\
\hline 18. & Slovenya & 881 & $0,8 \%$ & $€ 228.604 .103$ & $0,6 \%$ \\
\hline 19. & $\begin{array}{c}\text { Güney Kıbrıs Rum } \\
\text { Yönetimi }\end{array}$ & 522 & $0,5 \%$ & $€ 152.337 .537$ & $0,4 \%$ \\
\hline 20. & Romanya & 931 & $0,9 \%$ & $€ 148.818 .021$ & $0,4 \%$ \\
\hline 21. & Estonya & 495 & $0,5 \%$ & $€ 141.358 .113$ & $0,3 \%$ \\
\hline 22. & Luksemburg & 352 & $0,3 \%$ & $€ 110.055 .486$ & $0,3 \%$ \\
\hline 23. & Slovakya & 427 & $0,4 \%$ & $€ 93.284 .950$ & $0,2 \%$ \\
\hline 24. & Bulgaristan & 530 & $0,5 \%$ & $€ 79.639 .354$ & $0,2 \%$ \\
\hline 25. & Hırvatistan & 462 & $0,4 \%$ & $€ 71.883 .851$ & $0,2 \%$ \\
\hline 26. & Letonya & 314 & $0,3 \%$ & $€ 58.215 .558$ & $0,1 \%$ \\
\hline 27. & Litvanya & 362 & $0,3 \%$ & $€ 54.725 .557$ & $0,1 \%$ \\
\hline 28. & Malta & 148 & $0,1 \%$ & $€ 20.858 .104$ & $0,1 \%$ \\
\hline
\end{tabular}

Kaynak: Ufuk 2020, Dashboard

Tabloda belirtildiği üzere AB ülkeleri arasında en fazla projeye katılım gösteren ülke Almanya'dır. 2019 yılı verilerine göre AB'nin 13 bin 11 projeye katıldığı ve Ufuk 2020 Çerçeve Programı içerisinde gerçekleştirilen projelerin \%12,1'inde yer aldığı görülmektedir. Aynı zamanda Ufuk 2020 bütçesinden yapılan katkıların da \%15,6'sının Almanya'nın katıldığı projelere harcandığı görülmektedir. Almanya'dan sonra projelerden en fazla istifade eden ülke ise Birleşik Krallık'tır. Birleşik Krallık'ın katıldığı projelere, toplamda Ufuk 2020 bütçesinin \%13,6'sı tahsis edilmiştir. Birleşik Krallık’ı ise Fransa takip etmektedir. Fransa, 10 bin 531 proje katılımı ile Ufuk 2020 bütçesinin \%11'inin oluşturan projelere katılım göstermiştir. En fazla yararlanan ülkeler arasında 4. sirada İspanya, 5. sirada ise İtalya bulunmaktadır.

Ülkelerin çerçeve programı projelerine katılımları arasında önemli farklılıklar bulunmaktadır. Projelere en az katılım gösteren ülkeler sırasıyla; Malta, Litvanya, Letonya, Hırvatistan ve Bulgaristan'dır. Listenin ilk sırasında yer alan Almanya'nın listenin son sırasında yer alan Malta'dan yaklaşık 80 kat daha fazla projeye katıldığı görülmektedir.
Ancak bu değişken ele alınırken ülkelerin nüfusu ve buna bağlı olarak ar-ge personeli sayısı ihmal edilmemelidir. Nitekim yaklaşık 600 bin nüfuslu Malta ile 80 milyon nüfuslu Almanya'nın insan kaynağı altyapısı mukayese edilememektedir.

Aşağıdaki grafikte Avrupa Birliği ülkelerinin çerçeve programı proje sayısının ar-ge personeli ve araştırmacılara oranı verilmiştir (1000 personel başına düşen proje sayıs1).

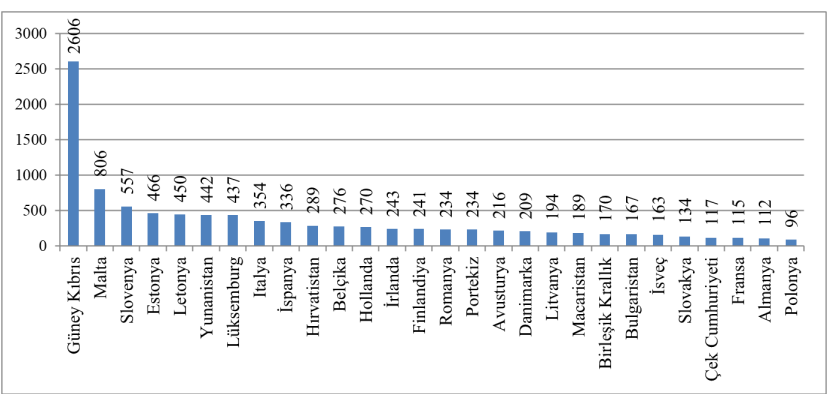

Şekil 2. Bin Ar-Ge Personeli / Araştırmacı Başına Düşen Ufuk2020 Proje Başvurusu (2016)

Kaynak: European Commission, 2018

2016 yılı verilerine göre Avrupa Birliği'nin Ufuk 2020 programı çerçevesinde proje başvuruları incelendiğinde, bin ar-ge personeli / araştırmacı başına en fazla proje başvurusu yapan AB ülkesinin Güney Kıbrıs olduğu sonucu çıkmaktadır. Güney Kıbrıs'ı Malta, Slovenya, Estonya, Letonya, Yunanistan ve Lüksemburg takip etmektedir. Bin ar-ge personeli/araştırmacı başına düşen Ufuk 2020 proje başvurusunda Belçika 11. sırada, Hollanda 12. sırada, Finlandiya 14. sırada, Avusturya 17. sirada yer alırken Danimarka ise 18. sırada yer almaktadır. Gelişmiş ve yenilikçi bir Kuzey Avrupa ülkesi olan İsveç ise listede 22. sirada yer almaktadır. Listede en az proje sunan ülke ise Polonya'dır. Avrupa Komisyonu'nun hazırlamış olduğu "Horizon 2020 in full swing" raporundan alınan veriler doğrultusunda Ufuk2020 programına İsveç, Finlandiya, Danimarka gibi ülkelerden araştırma alanında çalışan personele oranı kıyaslandığında diğer AB ülkeleri kadar katılım olmadığı tespit edilmiştir.

Çerçeve programlarının yararlanıcı ülkelere bilgi üretiminin artırılması, beşerî sermayenin gelişimi, uluslararası rekabet edebilirlik gücünün artırılması, yeni ürün ve hizmetlerin doğması gibi faydalar getirdiği bilinmektedir. Ancak bu faydaları sağlarken üye ülkelerin çerçeve programları bütçesine yapmış olduğu katkıları ve karşılığında almış oldukları proje hibelerinin de göz önünde bulundurulması gerekmektedir. Çerçeve programlarının bütçesi ekonomik güçlerine göre üye ülkelerin $\mathrm{AB}$ bütçesine yaptığı katkılardan gelmektedir.

AB ülkelerinin Ufuk 2020'den aldığı toplam fon miktarının nüfusa oranı hesaplandığında, en başarılı ülke Hollanda'dır. Hollanda şimdiye kadar kişi başına ortalama 179 bin 928 Euro fon edinmiştir. Hollanda'yı çok yakın bir miktar ile (179 bin 272 Euro) Lüksemburg takip etmektedir. Sonrasında ise Danimarka, Güney Kıbrıs ve 
Belçika gelmektedir. Kişi başına düşen fon miktarı en az olan ülkeler ise sırasıyla; Romanya, Polonya, Bulgaristan, Slovakya ve Hırvatistan'dır. 17,5 milyon nüfusu ile Hollanda'nın ilk sırada olması ve yaklaşık 20 milyon nüfuslu Romanya'nın en son sırada yer alması, AB ülkelerinin bilimsel proje üretebilme kabiliyetleri arasındaki farkı göz önüne sermektedir. Listenin ilk sırasındaki ülkede kişi başına yaklaşık 179 bin Euro fon kaynağı aktarılırken, son sırasındaki ülkeye yaklaşık 7 bin Euro fon kaynağı sunulmaktadır.

Tablo 3. Ufuk 2020 Bütçesinden Alınan Fon (Kişi Başına Alınan Fon)

\begin{tabular}{|c|c|c|c|c|c|}
\hline No & Ülke & $\begin{array}{c}\text { Kişi Başına } \\
\text { Alınan Fon }(\boldsymbol{\epsilon})\end{array}$ & No & Ülke & $\begin{array}{c}\text { Kişi Başına } \\
\text { Alınan Fon }(\boldsymbol{\epsilon})\end{array}$ \\
\hline 1. & Hollanda & 179.928 & 15. & Almanya & 76.781 \\
\hline 2. & Lüksemburg & 179.272 & 16. & Fransa & 67.020 \\
\hline 3. & Danimarka & 178.405 & 17. & Portekiz & 63.079 \\
\hline 4. & $\begin{array}{c}\text { Güney Kıbrıs Rum } \\
\text { Yönetimi }\end{array}$ & 174.466 & 18. & İtalya & 57.331 \\
\hline 5. & Belçika & 170.317 & 19. & Malta & 42.856 \\
\hline 6. & Finlandiya & 165.387 & 20. & Letonya & 30.349 \\
\hline 7. & İrlanda & 143.606 & 21. & Çek Cumhu- & 26.368 \\
\hline 8. & İsveç & 139.355 & 22. & Macaristan & 23.941 \\
\hline 9. & Avusturya & 128.750 & 23. & Litvanya & 19.607 \\
\hline 10. & Slovenya & 109.857 & 24. & Hırvatistan & 17.490 \\
\hline 11. & Estonya & 106.701 & 25. & Slovakya & 17.116 \\
\hline 12. & Yunanistan & 85.007 & 26. & Bulgaristan & 11.325 \\
\hline 13. & Birleşik Krallık & 83.385 & 27. & Polonya & 9.948 \\
\hline 14. & İspanya & 79.400 & 28. & Romanya & 7.619 \\
\hline
\end{tabular}

Kaynak: Ufuk 2020 Dashboard, Eurostat. Hesaplama: Yazar

Şimdiye kadar 18 bin 443 projeye, 85 bin 79 katılım ile 35 milyar 56 milyon Euro civarında katkı sunulmuştur (Ufuk 2020 Dashboard). Projeleri kabul edilen yararlanıcıların türleri aşağıdaki gibidir.

Tablo 4. Ufuk 2020 Yararlanıcılarının Türleri ve AB Katkısı

\begin{tabular}{|c|c|c|c|}
\hline Sıra & Kurum Türü & $\begin{array}{c}\text { AB Katkısı } \\
\text { (Milyar Euro) }\end{array}$ & $\begin{array}{c}\text { Toplam Katılma } \\
\text { Oranı }\end{array}$ \\
\hline 1. & $\begin{array}{c}\text { İkinci Seviye Eğitim Kurumları } \\
\text { ve Yükseköğretim Kurumları }\end{array}$ & 20,6 & $\% 39.1$ \\
\hline 2. & Özel şirketler & 15,2 & $\% 28.9$ \\
\hline 3. & Araştırma Kuruluşları & 13,3 & $\% 25,3$ \\
\hline 4. & Kamu Kurumları & 1,6 & $\% 3.1$ \\
\hline 5. & Diğer & 1,9 & $\% 3.6$ \\
\hline
\end{tabular}

Kaynak: Ufuk 2020 Dashboard, 2020

Tabloda belirtildiği üzere Ufuk 2020 Çerçeve Programı'na en fazla proje sunan kurumlar yükseköğretim kurumla- rıdır. Projelerin \%39.1'ine paydaș olarak program bütçesinden en fazla hibe alan kuruluşlar üniversitelerdir. Yükseköğretim kurumlarından sonra en fazla hibe alan aktörlerin özel şirketler olduğu görülmektedir. Kâr amacı gütmeyen araştırma kuruluşları ve kamu kurumları ise projelere katılma ve aldıkları hibe miktarları ile özel şirketlerin gerisinde kalmışlardır.

Avrupa Birliği genelinde çerçeve programlarından en fazla istifade eden ülkeler önceki kısımlarda belirtilmiști. $\mathrm{Bu}$ ülkelerin en fazla projeye katılım gösteren kurumları ise üniversiteler veya ulusal bilim politikalarını belirleyen kurumlarıdır. AB genelinde en fazla projeye katılan veya ortak olan ilk 5 kuruluş aşağıdaki gibidir.

Avrupa Birliği genelinde Ufuk 2020 Çerçeve Programı bünyesinde en fazla projeye katılan kurumların başında Fransa'nın Ulusal Bilimsel Araştırmalar Merkezi gelmektedir. Ardından Almanya'daki Fraunhofer Araştırma Örgütü gelmektedir. İlk 5 kurumun 2'si Fransa'ya, 1'i Almanya'ya, 1'i, İspanya'ya ve 1'i ise Birleşik Krallık'a aittir. Fransa, Almanya ve İspanya'dan siralamaya giren kurumların ulusal bilimsel araştırma koordinasyonundan sorumlu kurumlar olmasına karşın Birleşik Krallık'tan sıralamaya giren kuruluşun bir yükseköğretim kurumu olması oldukça şaşırtıcıdır.

\section{AB ÇERÇEVE PROGRAMLARINDA YÜKSEKÖĞRETIM KURUMLARININ ROLÜ}

Avrupa Komisyonu'nun bu konuda hazırlamış olduğu raporlar incelendiğinde $\mathrm{AB}$ tarafından çerçeve programları ile fonlanan ar-ge projelerindeki yenilik çıtılarının \%70'ine yükseköğretim kurumlarının katkı sunduğu görülmektedir. Rapora göre KOBİler ve üniversiteler arasındaki iş birliği oldukça tatmin edici düzeydedir. Özellikle yeni ürünlerin geliştirilmesi sürecinde üniversitelerin katkısı yadsınamaz. Özel şirketlerin birbiri ile yapmış olduğu iş birliği de projelerin oldukça önemli bir çıtısı olarak ortaya çıkmakta ve yeni süreç, hizmet ve örgütsel metotlar açısında önem arz etmektedir. Bu bağlamda üniversitelerin, yenilik üretimi sürecinde önemli role sahip olduğu ancak üretilen yeniliğin piyasada yer alması ve ticarileşebilmesi sürecinde özel şirketlerin daha önemli bir role sahip olduğu anlaşılmalıdır. Dolayısıyla üniversitelerin yenilik üretme sürecinde tamamlayıcı bir pozisyonda

Tablo 5. AB Genelinde Ufuk 2020'ye En Çok Katılım Gösteren 5 Kuruluş

\begin{tabular}{|c|c|c|c|c|}
\hline & Kurum Adı & Kurumsal Bilgi / Ülke / Şehir & Katılım Sayısı & Toplam Bütçe (Euro) \\
\hline 1. & CENTRE NATIONAL DE LA RECHERCHE SCIENTIFIQUE CNRS & $\begin{array}{l}\text { Fransa Ulusal Bilimsel Araştırmalar Merkezi (Fran- } \\
\text { sa-Paris) }\end{array}$ & 1,46 bin & 936,75 Milyon \\
\hline 2. & $\begin{array}{l}\text { FRAUNHOFER GESELLSCHAFT ZUR FOERDERUNG DER } \\
\text { ANGEWANDTEN FORSCHUNG E.V. }\end{array}$ & $\begin{array}{c}\text { Fraunhofer Araştırma Örgütü (Almanya genelinde } \\
69 \text { araştırma merkezi bulunmaktadır.) (Alman- } \\
\text { ya-Münih) }\end{array}$ & 880 & 538,32 Milyon \\
\hline 3. & $\begin{array}{l}\text { AGENCIA ESTATAL CONSEJO SUPERIOR DE INVESTIGACIO- } \\
\text { NES CIENTIFICAS }\end{array}$ & İspanya Ulusal Araştırma Konseyi (İspanya-Madrid & 616 & 262,96 Milyon \\
\hline 4. & $\begin{array}{l}\text { COMMISSARIAT À L'ÉNERGIE ATOMIQUE ET AUX ÉNERGIES } \\
\text { ALTERNATIVES }\end{array}$ & $\begin{array}{l}\text { Alternatif Enerjiler ve Atom Enerjisi Komisyonu } \\
\text { (Paris-Madrid) }\end{array}$ & 613 & 571,43 Milyon \\
\hline 5. & $\begin{array}{l}\text { THE CHANCELLOR, MASTERS AND SCHOLARS OF THE } \\
\text { UNIVERSITY OF OXFORD }\end{array}$ & Oxford Üniversitesi (Birleşik Krallık-Oxford) & 610 & 392, 52 Milyon \\
\hline
\end{tabular}

Kaynak: Ufuk 2020 Dashboard, 2020 
bulunduğu ve özel şirket veya KOBİlere katkı sunduğu belirtilmelidir. Üniversiteler ve özel kurulușlar bir yeniliğin piyasa potansiyelinin gerçeğe dönüștürülebilmesi için farklı gereksinimleri karşılamalı ve farklı rolleri yerine getirmelidir. Üniversiteler daha çok; sürecin ihtiyaç analizini yapma, raporlama, araştırma ve piyasaya sürülme öncesindeki nihai gereksinimleri hazırlama işleri ile ilgilenmektedirler. Özel şirketler ise söz konusu yeniliğin ticarileşebilmesi, ürün için piyasa oluşturulabilmesi ve piyasada yayılabilmesi gibi işlerle meşgul olmaktadırlar. Dolayısıyla $A B$ tarafindan fonlanan projeler sonrasinda ortaya çıkan yeniliklerin, her zaman bir dayanışma ürünü olduğu söylenebilir. Bu dayanışmada KOBİ'ler, yükseköğretim kurumları, araştırma kuruluşları ve özel sektör paydaştır (Pesole ve Nepelski, 2016: 31-34).

$A B$ tarafindan fonlanan proje sonrasında ortaya çıan yenilikler ticarileșebilme değerine göre düşük, orta veya yüksek potansiyelli yenilik olarak sınıflandırılmaktadırlar. Yeniliklerin potansiyele göre sınıflandırılmasında en büyük pay yeniliğin ticarileșebilme değerinden sonra yenilik üretme sürecindeki paydaşlara da bağlıdır. Aşağıdaki grafikte düşük, orta ve yüksek yenilik potansiyeli kategorilerinde yenilikçi aktörlerin iş birliği oranları görülmektedir.

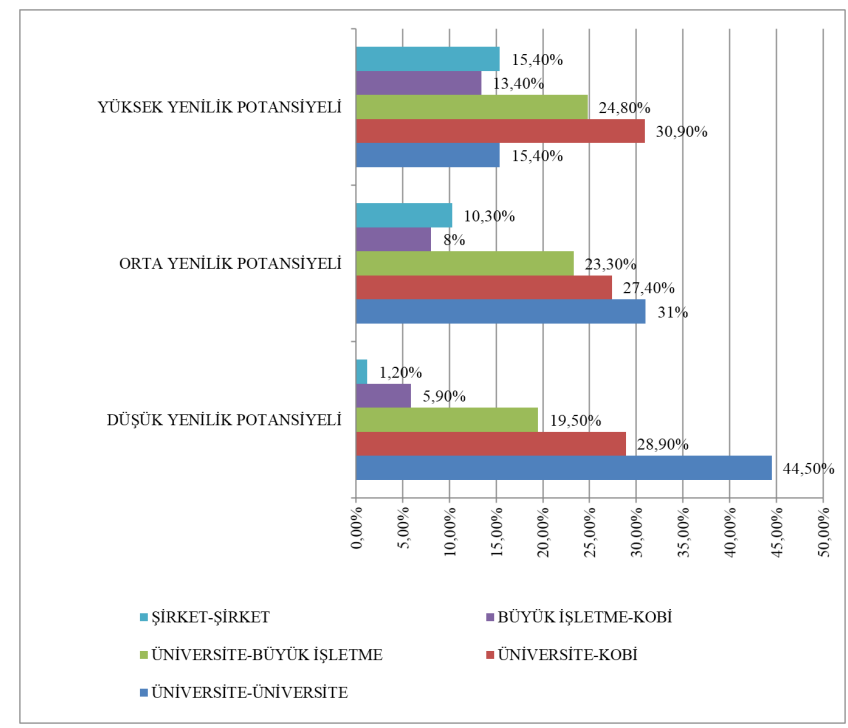

Şekil 3. İş Birliği Türü ve Yenilik Potansiyeli Kategorisine Göre Yenilik Aktörleri

Kaynak: EU Joint Research Centre ve European Commission The DirectorateGeneral for Communications Networks, Content and Technology.

Grafikte belirtildiği üzere yüksek yenilik potansiyelinin bulunduğu iş birliklerinde temel paydaşlar yaklaşık \%31'lik oran ile üniversiteler ve KOBİ'lerdir. Ardından yaklașlk \%15'lik bir oran ile üniversiteler ve büyük işletmeler arasındaki iş birliği gelmektedir. Sonrasında ise şirketler arasındaki ve üniversiteler arasındaki iş birlikleri gelmektedir.

Verilere göre üniversiteler birbirleriyle veya araştırma merkezleriyle iş birliği yaptıkça yenilik üretiminin potansiyeli zayıflamaktadır. Düşük yenilik potansiyeline sahip çıktılar incelendiğinde üniversite-üniversite iş birliğinin $\% 44,5$ oranında olduğu, dolayısıyla yükseköğretim kurumlarının birbiriyle yaptıkları iş birliklerinin en fazla 'düşük potansiyele sahip yenilik girişimlerinde' gerçekleştiği görülmektedir.

Yüksek potansiyelli yenilik, piyasada hızlı bir şekilde ticarileșebilen yeniliktir. Yüksek potansiyelli yenilik faaliyetlerine bakıldığında şirketlerin birbirleriyle yaptıkları iş birliklerinin yükseköğretim kurumlarının birbirleriyle yaptıkları iş birlikleri ile aynı katma değeri sunduğu görülmektedir. Bu durum, temel vazifesi araştırma ve geliștirme olan yükseköğretim kurumları için menfi bir çıktıdır. Yükseköğretim kurumlarının bu süreçteki rolü $\mathrm{AB}$ araștırma fonlarından istifade ederek bilimsel ve teknolojik bilgi üretmesi ve yenilik sürecine katkı sunmasıdır. Bu bağlamda yükseköğretim kurumlarının özel sektör ile iş birliği yaparak araştırmalarını ticarileştirebilmesi önem taşımaktadır.

Üniversitelerin özel sektör ve endüstri ile yaptığı iş birlikleri bilgi ekonomilerinde yenilik sürecinin oluşmasında önemli role sahiptir. Zira yükseköğretim kurumları işletmelere sağlanacak yenilikler için gerekli becerilere haizdir. Avrupa Komisyonu Ortak Araştırma Merkezi'nin çalışmalarına göre yüksek potansiyele sahip yeniliklerde, yenilik sürecinin \%70'i üniversitelerin ortaklıklarıyla gerçekleşmektedir. Üniversitelerin özellikle KOBI'lerle yaptığı iş birlikleri büyük firmalarla yaptığı iş birliklerine göre daha tatmin edicidir. Bu bağlamda yenilikçi ürün veya hizmetlerin özel kurumlar üzerinden geçerek piyasaya sürüldüğu bir ortamda üniversitelerin bu sürecin kaynağı olduğu söylenebilir. KOBI’lerin ise bu süreçte üniversitelerin desteği ile daha başarılı bir köprü vazifesi gördügünü belirtmek yanlış olmayacaktır (Pesole ve Nepelski, 2016: 48).

\section{SONUÇ}

İçerisinde bulunduğumuz bilgi çağında ekonomik anlamda rekabet edebilirliğinin güçlendirilmesi, verimliliğinin artırılabilmesi ve sürdürülebilir büyümenin tesis edilebilmesi için yenilik faaliyetlerine yatırım yapılması ve bu alanda politikalar belirlenmesi şart olmuştur. Avrupa Birliği de yenilik üretebilme kabiliyetini ve kapasitesini artırabilmek ve Birlik içerisindeki yenilik ekosistemini güçlendirerek bilim ve araştırma projelerini destekleyebilmek için yedi ylllık zaman dilimleri içerisinde çerçeve programları adıyla müstakil bir fon mekanizması kurmuştur. 2014-2020 yılları arasında geçerli olan Ufuk 2020 Çerçeve Programı ile Birliğin bilim, teknoloji, ar-ge ve yenilik faaliyetleri için yaklaşı 80 Milyar Euro'luk fon tahsis edilmiştir.

Ufuk 2020 Programı kapsamında desteklenen projelere katılım gösteren ülkelerin performansları incelendiğinde projelere en fazla paydaş olan ülkenin Almanya olduğu dikkat çekmiştir. Bu sonuç, Almanya'da bulunan üniversiteler, araştırma kuruluşları, özel şirketler ve STK'lar gibi kurum ve kuruluşların diğer ülkelere kıyasla daha iyi bir performans sergilediğini göstermektedir. Alman- 
ya'yı sırasıyla Birleșik Krallı, Fransa, İspanya ve İtalya takip etmektedir. Siralamada en başarısız olan ülke ise projelerde toplamda 148 defa temsil edilen Malta'dır. Almanya'daki kurumların projelere katılım sayısı, Malta'daki kurumların projelere katılım sayısının yaklaşık 89 mislidir. Projelerde yer alma oranı ve sıklığı ilgili ülkenin araştırmacı / ar-ge personeli ve yükseköğretim kurumu / araştırma merkezi sayısına bağlıdır. Nitekim Almanya gibi AB'nin en kalabalık ülkesinin Malta, Litvanya ve Letonya gibi az nüfuslu ülkelere göre daha fazla projede yer alabilmesi oldukça olağandır. Buna paralel olarak dikkate alınması gereken diğer bir gösterge araştırmacı başına düşen proje başvurularıdır. Almanya'da bin araştırmacı başına 112 proje başvurusu gerçekleşmekteyken, Malta'da bu sayı 806'dır. Bu bağlamda Malta'da araștırmacı başına düşen proje başvurusunun Almanya'dan yaklaşık 7 kat fazla olduğu görülmektedir. Malta bu sayı ile AB genelinde 2. sırada yer almaktadır. Güney Kıbrıs ise bin araștırmacı başına 2606 proje başvurusuyla $A B$ genelinde ilk sırada yerini almıştır. Listenin ilk sırasında yer alan Güney Kıbrıs'in araştırmacı başına düşen proje başvurusu dikkate alındığında listenin son sırasında yer alan Polonya'dan 27 kat daha fazla proje başvuru yaptığı gözlemlenmektedir.

Ülkelerin Ufuk 2020 Programı́ndan almış olduğu hibelerin vatandaşları başına oranına bakıldığında ise en kazançlı ülkelerin Lüksemburg, Lüksemburg ve Danimarka olduğu anlaşılmaktadır.

Ufuk 2020 Programı́na katılım gösteren ülkeler arasında proje katılımı ve projelerden elde edilen fon gibi göstergeler dikkate alındığında $\mathrm{AB}$ ülkeleri arasında derin uçurumların olduğu görülmektedir. Özellikle Ufuk 2020'ye sağlanan katkı ve karşıllığında edinilen hibeler göz önünde bulundurulduğunda $\mathrm{AB}$ ülkeleri arasında oldukça heterojen bir dağılımın oluştuğu söylenebilir.

Ufuk 2020 projelerinin katılan kurumların profilleri incelendiğinde ise yükseköğretim kurumlarının ve araștırma merkezlerinin birbirleriyle iş birliği yaptıkça yenilik üretebilme kabiliyetlerinin zayıfladığı görülmektedir. Projeler sonrasında ticarileșebilme değeri yüksek olan iş birliklerinin yükseköğretim kurumları ve ticari kaygı güden şirketler arasında gerçekleştiği ortaya çıkmıştır.

Avrupa Komisyonu, ilgili verileri inceleyerek yükseköğretim kurumlarının çerçeve programlarında daha fazla yer almasını sağlamalıdır. Nitekim yükseköğretim kurumlarının temel misyonlarından bir tanesi de araştırma faaliyetleridir. Bu tür faaliyetler için sağlanan hibelerin üye ülkelere dağılımında oldukça dengesiz bir tablo ortaya çıkmaktadır. Bu heterojen yapının da özellikle AB'ye yeni katılan ülkelerin yenilik üretebilme altyapısı ve kapasitesi dikkate alınarak çeşitli yasal mevzuatlar ile düzenlenmesi ve daha homojen bir yapının tesis edilmesi gerekmektedir.

\section{KAYNAKÇA}

Akçomak, i.S. (2016). Bilim, Teknoloji ve Yenilik Politikalarının Kuramsal Çerçevesi, (Ed.) Akçomak I.S., Erdil, E., Pamukçu, M.T. ve Tiryakioğlu, M., Bilim, Teknoloji ve Yenilik, İstanbul, İstanbul Bilgi Üniversitesi Yayınları.

Akses, S. (2010). AB Bilim ve Araştırma Politikası, Iktisadi Kalkınma Vakfı Yayınları, Yayın No:241, istanbul.

Conceiçao, P. ve Heitor M.V. (2005). Innovation for All?, London, Preeger.

European Commission (2013). Factsheet: Horizon2020 Budget, https://ec.europa.eu/research/horizon2020/pdf/press/ fact_sheet_on_horizon2020_budget.pdf.

European Commission (2015). Horizon Magazine EU Research Framework Programs 1984-2014, Directorate-General for Research and Innovation, Special Issue, Brussels.

European Commission (2018). Horizon2020 in full swing, Key Facts and Figures 2014-2016, Luxembourg, 2018.

European Defence Agency (2018). EU Framework Program for Research and Innovation, https://www.eda.europa.eu/procurement-biz/information/codeda-regulationaba/eu-framework-programme-for-research-and-innovation .

European Institute of Technology (2018). EIT as part of H2020, http://eit.europa.eu/eit-part-horizon2020.

EU Jint Research Centre (2014). European Research Area Dashboard-An Open Labour Market for Researchers, Brussels.

European Parliament (2015). Horizon 2020 Budget and Implementation, A guide to the structure of the programme, Brussels.

Fisch, P. (2017). Monetary distribution effects of Horizon 2020 An updated analysis, Coburg.

Harris, T. (2017). Collaborative Research and Development Projects, New York, Springer.

Karlson, C., Stough, R.R., Johansson, B. (2009). Introduction: Innovation and Entrepreneurship in Functional Regions, (Ed.) Karlsson, C., Entrepreneurship and Innovations in Functional Regions, Cheltenham, Edward Elgar Publishing.

Nepelski, D. Pesone, A., (2016). Universities and Collaborative Innovation in EC-funded Research Projects: An Analysis based on Innovation Radar Data, Luxembourg, European Commission.

Sabadie, J.A., Kwiatkowski, C. (2016). The Community Innovation Survey and the Innovation Performances of Enterprises Funded by EU's Framework Programmes, Brussels, European Commission.

Ufuk 2020 Dashboard. European Commission, H2020 Dashboard https://webgate.ec.europa.eu/dashboard. 